\title{
THE EFFECTS OF AN ADAPTED BASKETBALL TRAINING PROGRAM ON THE PHYSICAL FITNESS OF ADOLESCENTS WITH MENTAL RETARDATION: A PILOT STUDY
}

Zoran Stanisic ${ }^{1}$, Miodrag Kocic ${ }^{2}$, Marko Aleksandrovic ${ }^{2}$, Nemanja Stankovic ${ }^{2}$ and Dragan Radovanovic ${ }^{2}$

${ }^{1}$ “Sveti Sava” Elementary School, Pirot, Serbia

${ }^{2}$ Faculty of Sport and Physical Education University of Niš, Serbia

\author{
EFEIKATI SPECIJALNO PRILAGOĐENOG PROGRAMA KOŠARIKAŠKOG \\ TRENINGA NA FIZIČKU PRIPREMLJENOST ADOLESCENATA SA \\ MENTALNOM RETARDACIJOM: PILOT STUDIJA \\ Zoran Stanišić ${ }^{1}$, Miodrag Kocićn ${ }^{2}$ Marko Aleksandrović ${ }^{2}$, Nemanja Stanković ${ }^{2}$ i Dragan Radovanović ${ }^{2}$ \\ ${ }^{1}$ Osnovna škola “Sveti Sava”, Pirot, Srbija \\ ${ }^{2}$ Fakultet sporta i fizičkog vaspitanja Univerziteta u Nišu, Srbija
}

Received / Primljen: 28. 07. 2012.

Accepted / Prihvaćen: 17. 08. 2012.

\begin{abstract}
Introduction: Previous studies have established a direct connection between levels of physical fitness and the time needed to perform daily tasks in adults with intellectual disabilities. These findings indicate that physical activity can improve the quality of life of individuals with intellectual disabilities. The aim of this pilot study was to evaluate the effects of an eight-week specially adapted basketball training program on the physical fitness of adolescents with mental retardation.

Methods: Twelve adolescents (6 males and 6 females, mean age $15.1 \pm 1.5 \mathrm{yrs}$ ) with mental retardation participated in the study. A specially adapted basketball training program was conducted four times per week over eight consecutive weeks. Each training session lasted approximately 30 minutes. Anthropometric measurements included height, weight, and percentper cent body fat. Exercise testing included monitoring of heart rate (HR at rest and $H R$ at the end of the 6-MWT) and the six-minute walk test (6-MWT).
\end{abstract}

Results: The obtained results showed that the specially adapted training program improved the physical fitness of adolescents with mental retardation (6-MWT distance $473.7 m \pm 74.5$ pre vs. $672.6 m \pm 76.1$ post, $p<0.05$; HR at the end of the 6-MWT 122.1 beats/min \pm 16.5 pre vs. 116.8 beats/min \pm 9.4 post, $p<0.05$ ); however, this type of training did not decrease body weight or percentper cent body fat in the adolescent participants.

Conclusion: Considering the small number of participants who were involved in the study, the obtained results provide only limited information on the sources and magnitude of the variation in response measures, but these results support the design of a full-scale experiment on this topic.

Key words: mental retardation, basketball, training, physical fitness.

\section{SAŽETAK}

Uvod: Prethodne studije su utvrdile direktnu povezanost izmedu nivoa fizičke pripremljenosti $i$ vreme potrebnog za izvršavanje svakodnevnih zadataka kod odraslih osoba sa mentalnom retardacijom. Ovi nalazi ukazuju da fizička aktivnost može da poboljša kvalitet života osoba sa mentalnom retardacijom. Cilj sprovedenog pilot istraživanja bio je procena efekata osmonedeljnog specijalno prilagodenog programa košarkaškog treninga na fizičku pripremljenost adolescenata sa mentalnom retardacijom.

Metode: Dvanaest adolescenata (6 muškog i 6 ženkog pola, prosečne starosti $15,1 \pm 1,5 \mathrm{god}$ ) sa mentalnom retardacijom su učestvovali u studiji. Specijalno prilagođen program košarkog treninga sproveden je četiri puta nedeljno, tokom osam uzastopnih nedelja. Svaki trening je trajao oko 30 minuta. Antropometrijska merenja obuhvatila su određivanje telesne visine, telesne težine i procenta masnog tkiva, dok je testiranjem odredivana frekvencija rada srca (FS u mirovanju i FS na kraju 6 MTH) i predena razdaljina tokom šestominutnog testa hodanja (6 MTH).

Rezultati: Dobijeni rezultati su pokazali da je specijalno prilagođen program košarkog treninga doveo do poboljšanja fizičke pripremljenosti adolescenata sa mentalnom retardacijom (6 MTH razdaljina $473.7 m \pm 74.5$ pre vs. $672.6 m \pm 76.1$ post, $p<0.05$; FS na kraju 6 MTH 122.1 otkucaja/min \pm 16.5 pre vs. 116.8 otkucaja /min \pm 9.4 post, $p<0.05)$. Medutim, ova vrsta treninga nije dovela do smanjenja telesne težine ili procenta masnog tkiva ispitanika.

Zaključak: Obzirom na mali broj učesnika uključenih u studiju, dobijeni rezultati daju samo ograničene informacije o efektima sprovedenog programa, ali dozvoljavaju $i$ usmeravaju planiranje celovitog eksperimentalnog postupka na ovu temu.

Ključne reči: mentalna retardacija, košarka, trening, fizička pripremljenost. 


\section{INTRODUCTION}

Previous studies have indicated that individuals with intellectual disabilities score lower on standardised tests of physical fitness during all the phases of their life than do individuals with no out an intellectual disability $(1,2)$. For this reason, individuals who are intellectually disabled are often unable to adequately perform everyday activities and are limited in their work-related duties (3).

One of the latest studies in this area established a direct connection between levels of physical fitness and the time needed to perform daily tasks in adults with intellectual disabilities (4). These findings indicate that physical activity can improve the quality of life of individuals with intellectual disabilities. Furthermore, some studies have shown that physical inactivity and obesity among individuals with intellectual disabilities cause serious problems for their general health. For this reason, it is recommended that experts begin to include this population in various programs and initiatives for the promotion of health, including greater participation in physical activities (5). Muscle endurance and aerobic capacity can be so greatly reduced in intellectually disabled individuals as to impede the daily functioning of these persons (6). It is well known that muscle strength and balance decrease in adulthood in individuals with intellectual disabilities; at this same time,simultaneously, other health risks, such as weight gain and obesity, also develop (7). These factors additionally have a negative effect on physical fitness and increase the risk of a fall if, e.g., the stability of the surface under the subject were to be disturbed (8). Although certain studies have shown that differences in the level of intellectual disability can influence the level of physical ability and that individuals with a higher IQ show greater progress in terms of motor skills over a longer period of time (9), today it is believed that a lower level of physical fitness among individuals with intellectual disabilities is the consequence of a sedentary lifestyle and the lack of opportunity for these individuals to participate in any form of planned physical activity.

Regular physical activity can not only improve muscle strength and aerobic endurance but also balance and self-perception among individuals with intellectual disabilities (10). The participation of children and adults with intellectual disabilities in recreational activities and sports often improves their social inclusion and the overall quality of their lives (11). Nevertheless, obstacles often hinder participation in physical activities among individuals with intellectual disability. These obstacles include certain functional limitations of individuals, the lack of suitable objects, terrain or specialised programs, as well as the high cost of organising such forms of physical activity (12).

During adolescence, daily physical activity is essential for proper growth and development, improving health and decreasing the risk of cardiovascular and metabolic disorders in adulthood. The existing guidelines recommend at least 60 minutes of moderate-to-intense physical activity for adolescents several days a week (13). It is thus necessary to establish the preconditions for the physical activity of adolescents with intellectual disabilities, allowing them opportunities equal to those given of their peers.
The objective of this pilot study was to evaluate the effects of eight weeks of a specially adapted basketball training program on physical fitness in adolescents with mental retardation. It was hypothesised that adapted basketball training would provide significant training gains in adolescents with mental retardation.

\section{METHODS}

\section{The participants}

Twelve adolescents with mental retardation (mean age: $15.1 \pm 1.5$ yrs) participated in the study. All of the participants ( $\mathrm{n}=12,6$ males and 6 females) were classified as having mild mental retardation and lived at home; none were institutionalised. The study was approved by the Institutional Board of Special Schools for Elementary and Secondary Education "14 October" in Nis. Written informed consent was obtained from all the participants and from their parents or legal guardians (if indicated) after a detailed description of the procedures was provided. The procedures presented were in accordance with ethical standards set for human experimentation.

All of the participants underwent a physical examination for athletic eligibility, which was performed by a specialist in sports medicine. None of the participants showed any evidence of recent injury in their anamnesis or clinical report.

\section{Training procedures}

A specially adapted basketball training program was conducted four times per week over eight consecutive weeks. Each training session lasted approximately 30 minutes. The first 5 minutes were spent in a dynamic warm-up to set the tone for the training session, and the last 5 minutes were spent doing stretching exercises to help relax the body. Over the eight-week period, the subjects had 32 training sessions in total. The duration of the training sessions during the first four weeks ranged from 25 to $30 \mathrm{~min}$, extending to 30 to 35 min after fourth week. The main training activities in the first four weeks of the program included ball handling, reception and passing. From the fifth week until the end of the program, shooting and playing basketball were added.

\section{Measurements and exercise testing procedures}

Anthropometric measurements included height, weight, and percentper cent body fat. Heights were measured using an anthropometer (GPM, Switzerland) in accordance with standardised procedure (14). The results were accurate within $0.1 \mathrm{~cm}$. Weights were measured using electronic scales (Tefal, France) with an accuracy within $0.1 \mathrm{~kg}$. Body compositions were measured by bioelectrical impedance analysis using the BF 300 (Omron, Japan) according to the manufacturer's instructions. PercentThe percentages of body fat were read off the display with an accuracy of $0.1 \%$. The resting heart rates and heart rates during the six-minute walk test (6-MWT) were determined continuously using an automated telemetric monitoring system (Polar, Finland). 
To evaluate the general and integrated responses of the organ systems involved in physical activity, the six-minute walk test was used (15). The test does not offer any concrete information regarding the function of each of the various organs and systems involved in physical activity, as is possible with standardised laboratory load tests using suitable equipment for cardio-pulmonary studies. Nevertheless, as most of the daily activities take place below maximal intensity, the 6-MWT offers sufficient insight into the functional state of the bodies of the participants for daily physical activities $(15,16)$. This test was used in previous research involving individuals with special needs, including those suffering from mental retardation (17).

The six-minute walk test, conducted at the participant's own pace on a flat surface $30 \mathrm{~m}$ in length, in a gym, was carried out according to a standardised protocol while adhering to the existing recommendations $(15,16)$. The participants were assigned the task of crossing as great a distance as possible in a period of $6 \mathrm{~min}$, walking (but not running) at a tempo that suited them. The participants received instructions and were continuously motivated during the test. In addition, the participants were allowed to stop at any point during the test but were encouraged to resume in the shortest possible time. The distance covered in 6 min was measured to the closest meter. To simplify measurement, alternating fluorescent green and orange markers were placed at 1-m intervals of along the edge of the surface on which the test was being carried out.

\section{Statistical Analyses}

The Kolmogorov-Smirnov test of normality was performed on all variables. All of the data were normally distributed, and a paired $\mathrm{t}$-test was used to compare physical fitness and specific motor skills before and after the eight weeks of the specially adapted basketball training program. The data were described as the means \pm standard deviation (SD). Statistical significance was set at $\mathrm{p}<0.05$ for all statistical analyses.

\section{RESULTS}

The results of this pilot study are presented as the means and standard deviation in Tables 1 and 2. The eightweek specially adapted basketball training program did not result in any statistically significant changes in body weight and body fat percentage (Table 1).

\begin{tabular}{|l|l|l|l|l|l|}
\hline \multirow{2}{*}{ Variables (unit) } & \multicolumn{2}{|c|}{ Before } & \multicolumn{2}{c|}{ After } & \multirow{2}{*}{ p value } \\
\cline { 2 - 5 } & Mean & \multicolumn{1}{|c|}{ SD } & Mean & \multicolumn{1}{|c|}{ SD } & \\
\hline Body height $(\mathrm{cm})$ & 155.5 & 14.8 & 155.9 & 15.1 & $\mathrm{~ns}$ \\
\hline Body weight $(\mathrm{kg})$ & 55.6 & 16.6 & 55.1 & 15.8 & $\mathrm{~ns}$ \\
\hline Body fat mass $(\%)$ & 21.1 & 6.8 & 20.4 & 6.3 & $\mathrm{~ns}$ \\
\hline
\end{tabular}

Table 1. The anthropometric variables of the participants $(n=12)$ before and after eight weeks of a specially adapted basketball training program.
Significant changes in heart rate at the end of the 6-MWT were recorded for the participants after eight weeks of a specially adapted training program (Table 2).

\begin{tabular}{|l|l|l|l|l|l|}
\hline \multirow{2}{*}{ Variables (unit) } & \multicolumn{2}{|c|}{ Before } & \multicolumn{2}{c|}{ After } & \multirow{2}{*}{ p value } \\
\cline { 2 - 5 } & Mean & SD & Mean & SD & \\
\hline $\begin{array}{l}\text { Resting heart rate } \\
\text { (beats/min) }\end{array}$ & 84.4 & 9.5 & 82.3 & 8.4 & ns \\
\hline $\begin{array}{l}\text { Heart rate at the end } \\
\text { of the 6-MWT } \\
\text { (beats/min) }\end{array}$ & 122.1 & 16.5 & 116.8 & 9.4 & $\mathrm{p}<0.05$ \\
\hline
\end{tabular}

Table 2. The participants' heart rates at rest and at the end of the 6-MWT $(n=12)$ before and after eight weeks of a specially adapted basketball training program.

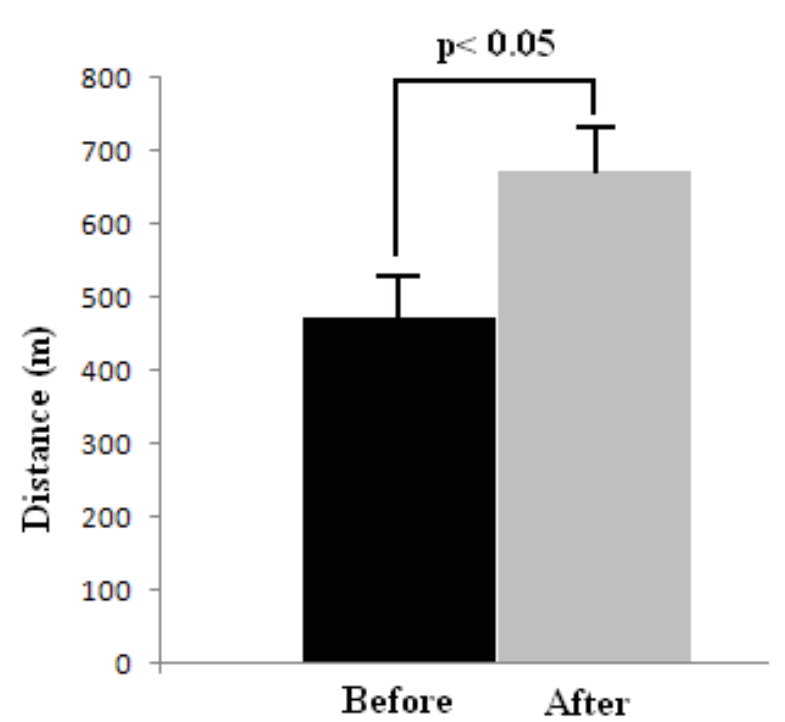

Figure 1. The significant differences in the distance covered during the six-minute walk test (6-MWT) before and after eight weeks of a specially adapted basketball training program.

\section{DISCUSSION}

Young individuals with intellectual disabilities (aged 2030) usually have cardio-respiratory endurance $8-12 \%$ lower and maximum heat rates 15 beats/min lower than the expected values for non-disabled individuals of the same gender and age $(18,3)$. Approximately $20 \%$ of adults with intellectual disabilities were classified as obese, with a strong inverse relationship between intelligence and the percentage of body fat (19). A comparison of muscle strength at the elbow and knee joints of young individuals with intellectual disabilities with the values obtained from a non-disabled population of the same age and gender found that these values were $35-40 \%$ lower in disabled individuals (20); this finding is likely connected to the predominantly sedentary lifestyle of individuals with intellectual disabilities. One of the few studies examining flexibility indicated that there 
are no significant differences between individuals with intellectual disabilities and a non-disabled population of the same gender and age (21). As a consequence, the lower level of physical preparation among individuals with intellectual disabilities is considered to be "related to the type of disability ", even though a sedentary lifestyle is the primary cause (22). For this reason, whatthe extent to which the level of physical fitness among individuals suffering from intellectual disabilities reflects their full potential is unclear.

In the case of physically healthy individuals, the function of the cardiovascular system represents a limiting factor for taking part in physical activities. The parameters of the function of the cardiovascular system, especially heart rate, are strongly correlated with oxygen uptake and energy consumption, especially below maximal work. The results of the pilot study indicate that eight weeks of a specially adapted basketball training program initiated a process of physiological adaptation, resulting in a statistically significant decrease in heart rate at the end of the 6-MWT (Table 2).

On the basis of the statistically significant differences in the covered distance during the 6-MWT (Figure 1), we conclude that the specially adapted basketball training program led to an improvement in function. Nevertheless, the level of physical activity and/or its duration were not sufficient to lead to statistically significant changes in body weight and percentage of body fat. Nevertheless, the results show a difference, and so we assume that an increase in program duration or work intensity could lead to a statistically significant decrease in body fat.

Sport can play an important role in the lives of individuals with intellectual disabilities, as it presents a good foundation for the development of physical abilities and improvement of the quality of life of individuals with mental retardation. Objective problems such as a lack of suitable equipment, fields, or specialised programs, as well as the high cost of organising such forms of physical activity, can be overcome through a variety of different adapted basketball training programs, under the guidance of a dedicated and qualified physical -education teacher with regular medical monitoring. The tests proposed in this pilot study could be useful for monitoring early improvements in adolescents with mental retardation.

Considering the small number of participants who were involved in the study, more research is needed to establish the effectiveness of adapted basketball training programs for adolescents with mental retardation before specific training recommendations can be made.

\section{CONCLUSION}

This pilot study demonstrated that eight weeks of a specially adapted basketball training program improved physical fitness in adolescents with mental retardation. Such physical activity and the nature of basketball, which necessitates interaction and decision-making in a variety of situations, can be a means of improving interaction and promoting connections among members of this population. Such programs also help to form a good foundation for the development of physical abilities and improve quality of life. The results of this pilot study provide only limited information on the sources and magnitude of the variation of the response measures, but these results support the design of a full-scale experiment on this topic.

\section{REFERENCES}

1. Chanias AK, Reid G, Hoover ML. Exercise effects on health related physical fitness of individuals with an intellectual disability: A meta-analysis. Adapt Phys Activ Q 1998; 15: 119-40.

2. Graham A, Reid G. Physical fitness of adults with an intellectual disability: A 13-year follow-up study. Res Q Exerc Sport 2000; 71: 152-61.

3. Fernhall B, Pitetti KH. Limitations to work capacity in individuals with intellectual disabilities. Clin Exerc Physiol 2001; 3: 176-85.

4. Cowley PM, Ploutz-Snyder LL, Baynard T, et al. Physical fitness predicts functional tasks in individuals with Down syndrome. Med Sci Sport Exerc 2010; 42(2): 388-93.

5. Rimmer JH, Heller T, Wang E, Valerio I. Improvements in physical fitness in adults with Down syndrome. Am J Mental Retard 2004; 109: 165-74.

6. Carmeli E, Barchad S, Lenger R, Coleman R. (2002). Muscle power, locomotor performance and flexibility in aging mentally-retarded adults with and without Down's syndrome. J Musculoskelet Neuronal Interact 2002; 2(5): 457-62.

7. Lahtiner U, Rintala P, Malin A. Physical performance of individuals with intellectual disability: A 30 year follow up. Adapt Phys Activ Q 2007; 24(2): 125-43.

8. Hale L, Bray A, Littmann A. Assessing the balance capabilities of people with profound intellectual disabilities who have experienced a fall. J Intell Disab Res 2007; 51(4): 260-8.

9. Beadle-Brown J, Murphy G, Wing L, Gould J, Shah A, Holmes N. Changes in skills for people with intellectual disability: a follow-up of the Camberwell Cohort. J Intell Disabil Res 2000; 44: 12-24.

10. Carmeli E, Zinger-Vaknin T, Morad M, Merrick J. Can physical training have an effect on well-being in adults with mild intellectual disability? Mech Ageing Dev 2005; 126(2): 299-304.

11. Wilson PE. Exercise and sports for children who have disabilities. Phys Med Rrehabil Clin N Am 2002; 13(4): 907-23.

12. King G, Law M, King S, Rosenbaum P, Kertoy MK, Young NL. A conceptual model of the factors affecting the recreation and leisure participation of children with disabilities. Phys Occup Ther Pediatr 2003; 23(1): 63-90.

13. Strong W, Malina RM, Blimkie CJR. Evidence based physical activity for school-age youth. J Pediatr 2005; 146: $732-7$. 
14. Eston R, Reilly T. Kinanthropometry and exercise physiology laboratory manual: tests, procedures and data. Volume 2: Exercise physiology. 2nd ed. London: Routledge, 2001.

15. American Thoracic Society Statement. Guidelines for the six-minute walk test. ATS committee on proficiency standards for clinical pulmonary function laboratories. Am J Respir Crit Care Med 2002; 166(1): 111-7.

16. Enright PL. The six-minute walk test. Respir Care; 48: 783-5.

17. Elmahgoub SM, Lambers S, Stegen S, Van Laethem C, Cambier D, Calders P. The influence of combined exercise training on indices of obesity, physical fitness and lipid profile in overweight and obese adolescents with mental retardation. Eur J Pediatr 2009; 168: 1327-33.

18. Fernhall B, Pitetti KH, Rimmer JH, McCubbin JA, Rintala P, Millar AL, Kittredge J, Burkett LN. Cardio respiratory capacity of individuals with mental retarda- tion including Down syndrome. Med Sci Sports Exerc 1996; 28: 366-71.

19. Hove O. Weight survey on adult persons with mental retardation living in the community. Res Dev Dis 2004; 25: 9-17.

20. Horvat M, Pitetti KH, Croce R. Isokinetic torque, average power, and flexion/extension ratios in nondisabled adults and adults with mental retardation. J Orthop Sports Phys Ther 1997; 25: 395-9.

21. Frey GC, McCubbin JA, Hannigan-Downs S, Kasser SL, Skaggs SO. Physical fitness of trained runners with and without mild mental retardation. Adapt Phys Activ Q 1999; 16: 126-37.

22. Draheim CC, Williams DP, McCubbin JA. Physical activity, dietary intake, and the insulin resistance syndrome in nondiabetic adults with mental retardation. Am J Ment Ret 2002; 107: 361-75. 